\title{
Protein Spin Labeling with a Photocaged Nitroxide Using Diels-Alder Chemistry**
}

\author{
Anandi Kugele ${ }^{+}$, Bjarne Silkenath ${ }^{+}$, Jakob Langer, Valentin Wittmann, ${ }^{*}$ and Malte Drescher ${ }^{*[a]}$
}

\begin{abstract}
EPR spectroscopy of diamagnetic bio-macromolecules is based on site-directed spin labeling (SDSL). Herein, a novel labeling strategy for proteins is presented. A nitroxide-based spin label has been developed and synthesized that can be ligated to proteins by an inverse-electron-demand Diels-Alder $\left(\mathrm{DA}_{\text {inv }}\right)$ cycloaddition to genetically encoded noncanonical amino acids. The nitroxide moiety is shielded by a photoremovable protecting group with an attached tetra(ethylene glycol) unit to achieve water solubility. SDSL is demonstrated on two model proteins with the photoactivatable nitroxide for $\mathrm{DA}_{\text {inv }}$ reaction (PaNDA) label. The strategy features high reaction rates, combined with high selectivity, and the possibility to deprotect the nitroxide in Escherichia coli lysate.
\end{abstract}

EPR spectroscopy together with site-directed spin labeling (SDSL) is a valuable and established tool to elucidate structure, function, and dynamics of proteins and protein complexes. ${ }^{[1]}$ Nitroxide-based spin labels are the best established and most convenient ones, ${ }^{[2]}$ because they are small, nondisturbing, and exhibit excellent spectroscopic properties. ${ }^{[3]}$ In particular, they are perfect to display rotational dynamics through line-shape analysis ${ }^{[3 a, 4]}$ and can be used for distance determination. ${ }^{[5]}$ The most commonly used spin label for EPR spectroscopy is the methanethiosulfonate spin label (MTSSL). ${ }^{[\mathrm{b}]}$ It reacts specifically with accessible sulfhydryl moieties in proteins, that is, cysteine residues. MTSSL application requires elimination of native cysteine residues by genetic engineering and the introduction of strategically positioned residues. Alternative native amino acids, such as tyrosine, were also utilized for spin labeling. ${ }^{[6]}$ However, the choice of native amino acids as tags for spin labels limits bioorthogonality. If selecting genetically encoded noncanonical amino acids (ncAAs) as targets for SDSL instead,

[a] A. Kugele, ${ }^{+}$B. Silkenath, ${ }^{+}$J. Langer, Prof. Dr. V. Wittmann

Prof. Dr. M. Drescher

Department of Chemistry and

Konstanz Research School Chemical Biology (KoRS-CB)

University of Konstanz

Universitätsstrasse 10, 78457 Konstanz (Germany)

E-mail:mail@valentin-wittmann.de malte.drescher@uni-konstanz.de

$\left.{ }^{[+}\right]$These authors contributed equally to this work.

${ }^{* *}$ A A previous version of this manuscript has been deposited on a preprint server (https://doi.org/10.26434/chemrxiv.7931192)

$\square$ Supporting information and the ORCID identification numbers for the

(D) authors of this article can be found under https://doi.org/10.1002/ cbic.201900318.

of (c) 2019 The Authors. Published by Wiley-VCH Verlag GmbH \& Co. KGaA This is an open access article under the terms of the Creative Commons Attribution License, which permits use, distribution and reproduction in any medium, provided the original work is properly cited. selectivity can be achieved, even in cells, and removal of functionally relevant cysteine residues is not required. ${ }^{[7]}$ The use of an orthogonal aminoacyl-tRNA-synthetase (aaRS)-tRNA pair capable of selectively charging a nonsense suppressor tRNA (e.g., an amber codon) with an ncAA is an established method ${ }^{[8]}$ Expansion of the genetic code by the incorporation of ncAAs has resulted in a plethora of potential conjugation techniques because a broad range of ncAAs with specific reactivities are available. ${ }^{[9]}$

However, in combination with spin labeling, only a few ncAAs and corresponding chemical reaction schemes have been employed, to date. ${ }^{[10]}$ An ideal spin labeling procedure should exhibit high reaction rates, but still be selective. Independence from any potentially cytotoxic catalysts further simplifies the reaction, while water solubility is a prerequisite for in vivo use. Gadolinium(III)- and trityl-based spin labels are stable in cells. They have been used for distance measurements, but suffer either from a very broad spectrum and resulting low modulation depths or from a very narrow spectrum not suitable for double-frequency experiments. ${ }^{[10 b, 11]}$ Nitroxides provide ideal spectral width and additionally access to dynamic information. However, traditional nitroxide-based labels feature limited redox stability in the cellular environment and their EPR signal vanishes within minutes. ${ }^{[12]}$ Thus, for routine in vivo use, it is crucial to increase the nitroxide stability. Recently, a tetraethyl-modified maleimido-PROXYL-based (PROXYL: 2,2,5,5tetramethyl-1-pyrrolidinyloxy) spin label with enhanced stability was introduced. ${ }^{[13]}$

We present herein a novel approach to address both ncAAmediated spin labeling and nitroxide stability (Figure 1). Introduction of the novel label is achieved through the $\mathrm{DA}_{\text {inv }}$ reaction $^{[14]}$ of a 1,2,4,5-tetrazine with a strained alkyne (cyclooctyne, $\mathrm{SCO})^{[15]}$ or alkene (trans-cyclooctene, TCO). ${ }^{[16]}$ This reaction forms the corresponding pyridazine and dihydropyridazine, respectively. Due to its excellent water compatibility, the $D A_{\text {inv }}$ reaction has proven to be suitable for a broad range of biochemical applications both in vitro and in vivo. ${ }^{[14,17]}$ Strain-promoted $D_{\text {inv }}$ cycloadditions have not been used for the SDSL of proteins so far (notably, recently an in vitro transcribed RNA segment was site-specifically labeled with a tetrazine-nitroxyl moiety $\left.{ }^{[18]}\right)$. Moreover, we aimed to address nitroxide stability by using a protection strategy. So far, alkylation, ${ }^{[19]}$ silylation, ${ }^{[20]}$ acylation, ${ }^{[21]}$ and photoremovable protecting groups (PPGs) ${ }^{[22]}$ have been demonstrated to protect nitroxides and to release them as needed. In particular, photoirradiation for deprotection is interesting because it enables spatial and temporal control over the release of functional groups. In particular, o-nitrobenzyl derivatives for diverse functionalities, even for native amino acid side chains, ${ }^{[23]}$ were pioneered in 1966 and have 
A)

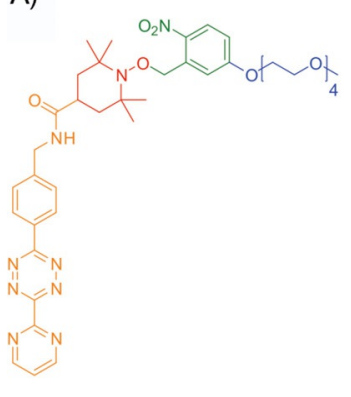

1 (PaNDA spin label)
B)

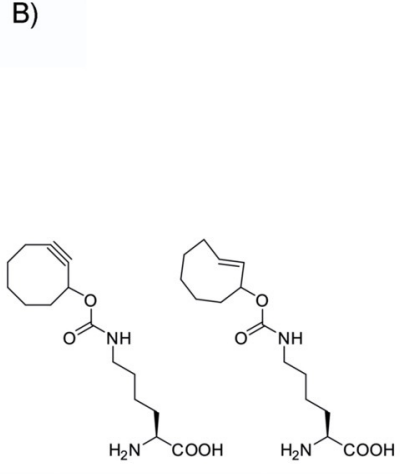

$2 a$

$3 a$

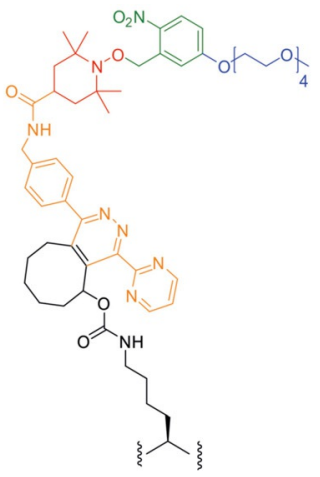

$2 b$

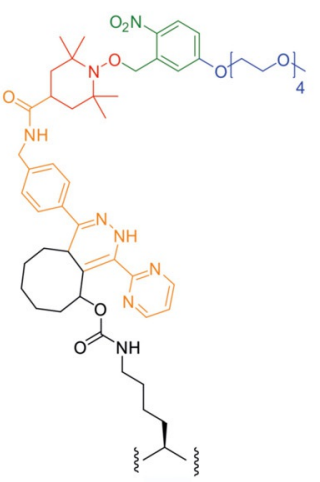

3b

C)
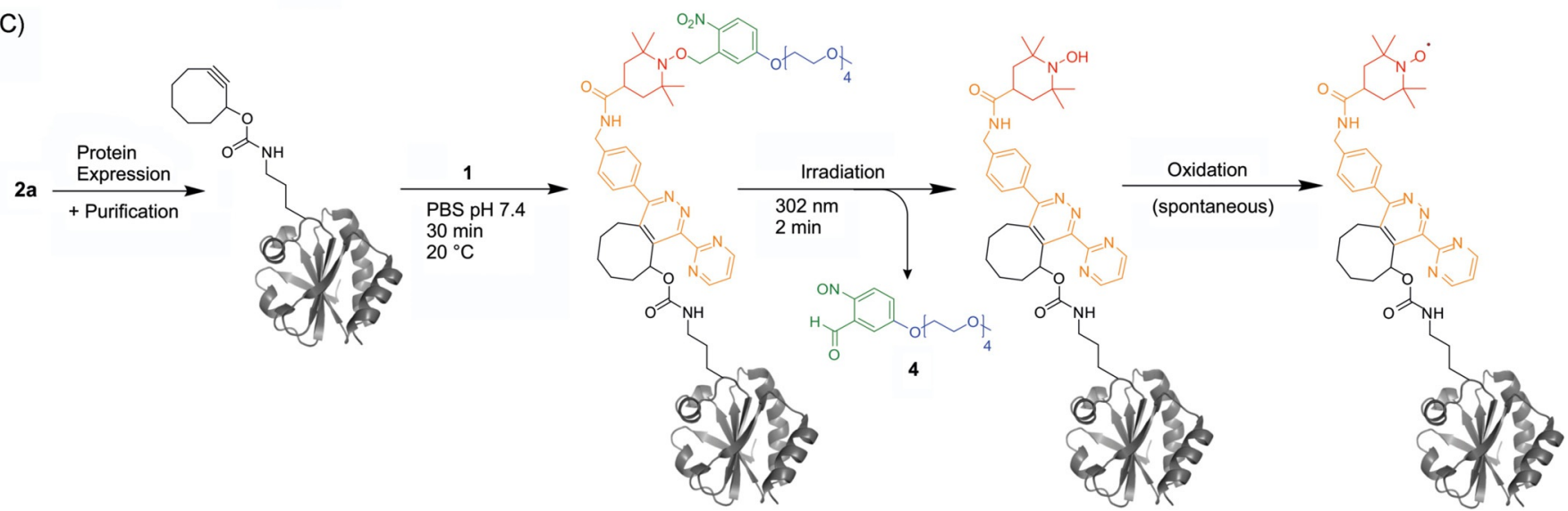

Figure 1. Protein labeling with the photoactivatable nitroxide for $\mathrm{DA}_{\text {inv }}$ reaction (PaNDA; $\mathrm{DA}_{\text {inv }}$ : inverse-electron-demand Diels-Alder) label. A) Structure of PaNDA spin label 1, with its particular functional features colored in orange (tetrazine moiety), red (photocaged (2,2,6,6-tetramethylpiperidin-1-yl)oxyl (TEMPO)), and green (photoremovable protecting group (PPG), with a tetra(ethylene glycol) chain in blue). B) Structures of the ncAAs $N^{6}$-[(cyclooct-2-yn-1yloxy)carbonyl]-L-lysine ( $\mathbf{2}$ a) and $N^{6}$-(\{[(E)-cyclooct-2-en-1-yl]oxy\}carbonyl)-L-lysine ( $\mathbf{3}$ a) used in this study. The respective products upon reaction with $\mathbf{1}$ are shown as $\mathbf{2} \mathbf{b}$ and $\mathbf{3} \mathbf{b}$ for the ncAAs $\mathbf{2} \mathbf{a}$ and $\mathbf{3}$ a, respectively. C) Incorporation of the ncAA into proteins (exemplarily shown for TRX-R74 $\rightarrow \mathbf{2}$ a (PDB ID: $\left.2 T_{R X}^{[27]}\right)$ ), and in vitro labeling and deprotection conditions. PBS: phosphate-buffered saline.

since become the best established PPGs. ${ }^{[24]}$ Their application for the protection of nitroxide spin labels during oligonucleotide synthesis was introduced by Seven et al. in $2014^{[22]}$ and continued by Weinrich et al. ${ }^{[25]}$

Figure $1 \mathrm{~A}$ depicts the structure of the new spin label, named PaNDA. It is composed of a 3,6-diaryl-substituted 1,2,4,5-tetrazine as the diene component of a $D A_{\text {inv }}$ reaction attached to an o-nitrobenzyl-protected TEMPO derivative, which delivers an EPR-active nitroxyl radical upon photoirradiation and subsequent air oxidation. Oligoethylene glycol chains have been used previously to enhance the water solubility of tetrazine derivatives. ${ }^{[26]}$ Accordingly, we attached a tetra(ethylene glycol) monomethyl ether to ensure water solubility of the PaNDA label. This approach is elegant, insofar as the rather bulky PPG, along with the tetra(ethylene glycol) chain, is cleaved off by irradiation.

For the synthesis of PaNDA label 1, carboxy TEMPO 5 was quantitatively transformed into hydroxylammonium salt 6 by making use of the acid-dependent redox triad of a nitroxyl radical, an oxoammonium cation, and hydroxylamine (Scheme $1 \mathrm{~A}) .{ }^{[28]}$ Conveniently, the carboxylic acid is simultane- ously protected under these conditions. Nitrobenzaldehyde 7 was reduced to the benzyl alcohol and the phenol group was selectively alkylated with tetraethylene derivative 8 to yield nitrobenzyl alcohol 9 (Scheme 1B). The Appel reaction gave benzyl bromide 10, which was used to alkylate 6 followed by ester hydrolysis to yield carboxylic acid 11. Finally, amide bond formation with tetrazine derivative $12^{[29]}$ delivered PaNDA label 1 in an overall yield of $42 \%$, starting from nitrobenzaldehyde 7.

To initially test and optimize the deprotection step, we evaluated the UV/Vis absorption spectrum of the PaNDA spin label (Figure $2 \mathrm{~A}$ ). It exhibits a prominent feature for the photocage group at $\lambda \approx 300 \mathrm{~nm}$. To this end, we tested the time-dependent deprotection efficiency at $\lambda=302 \mathrm{~nm}$. LC-MS analysis of the PaNDA spin label proved almost complete conversion to the desired nitroxide after irradiation for $10 \mathrm{~min}$ (Figure 2B). Accordingly, an EPR signal appeared only after irradiation (Figure $2 \mathrm{C}$ ).

To test and establish our labeling and deprotection method with proteins, we chose green fluorescent protein (GFP) and Escherichia coli oxidoreductase thioredoxin (TRX). TRX was the 
A)
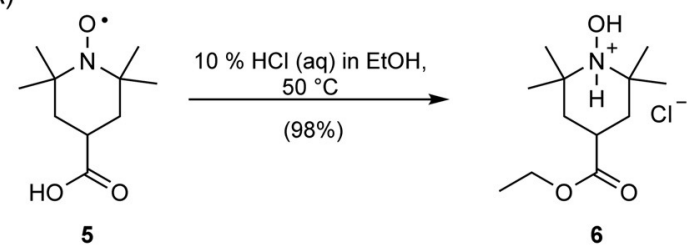

B)<smiles>O=Cc1cc(O)ccc1[N+](=O)[O-]</smiles>

1) $\mathrm{NaBH}_{4}, \mathrm{THF}$
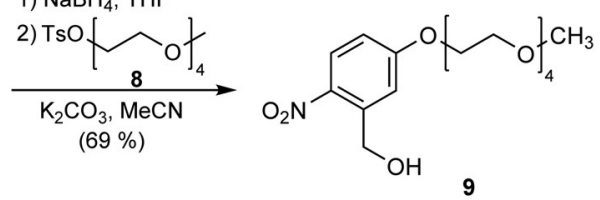

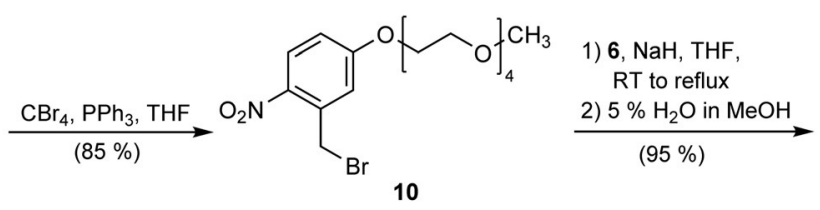<smiles>CCCOc1ccc([N+](=O)[O-])c(CON2C(C)(C)CC(C(=O)O)CC2(C)C)c1</smiles>

11

Scheme 1. Synthesis of PaNDA label 1. Ts: toluenesulfonyl, NMM: N-methylmorpholine, PyBOP: benzotriazol-1-yloxytripyrrolidinophosphonium hexafluorophosphate.

first protein to be modified by a $\mathrm{DA}_{\text {inv }}$ reaction in $2008,{ }^{[16 a]}$ and previous EPR studies are available for data comparison. ${ }^{[10 e, 30]}$ Both model proteins exhibit native cysteine residues; thus providing the possibility to test for orthogonal labeling without affecting cysteine. The first ncAA that could undergo a $D A_{\text {inv }}$ reaction, a lysine-derived cyclooctyne, was introduced for the copper-free click reaction in $2011{ }_{1}^{[31]}$ before a tetrazine ${ }^{[32]}$ norbornenes, ${ }^{[15 a, 33]}$ TCOs, $^{[15 a]}$ and a spirohexene ${ }^{[34]}$ were also genetically encoded. The rationally designed Methanosarcina mazei mutant tRNA Pyl $^{\text {PyIRS }}{ }^{\text {AF }}$ (Y306A, Y384F) possesses an enlarged binding pocket that is suitable for incorporating these bulky ncAAs in response to the amber stop codon. ${ }^{[15 a, 31,35]}$ Therefore, we coexpressed amber stop codon mutants of C-terminally $\mathrm{His}_{6}$-tagged model proteins, together with the previously reported tRNA ${ }^{\text {Pyl }} /$ PyIRS $^{A F}$ synthetase in E. coli. We tested two different ncAAs, namely, $\mathbf{2} \mathbf{a}$ and $\mathbf{3}$ a (Figure $1 \mathrm{~B}$ ), which are well known for high integration rates and exhibit excellent reaction kinetics. ${ }^{[15 a, 36]}$ Expression in the presence of $1 \mathrm{~mm}$ ncAA yielded between 4 and $7 \mathrm{mgL}^{-1}$ of purified full-length GFP-Y39 $\rightarrow \mathbf{2} \mathrm{a}$, GFP-Y39 $\rightarrow \mathbf{3 a}$ ，TRX-R74 $\rightarrow \mathbf{2}$ a， or TRX-R74 $\rightarrow \mathbf{3}$ a, respectively (Figures S11-S12 and S16-S17 in the Supporting Information). We even succeeded in the incorporation of the SCO-bearing amino acid $2 \mathrm{a}$ in response to two amber stop codons in a protein, which was, to the best of our knowledge, not reported previously (TRX-G34/R74 $\rightarrow \mathbf{2}$ a; Figure S13).

Next, we wanted to assess the spin labeling potential of the ncAA-containing proteins with the PaNDA spin label in vitro (for the general procedure, see Figure $1 \mathrm{C}$ ). For this purpose, we mixed the purified proteins with the PaNDA spin label and established mild and universally applicable reaction conditions $\left(30 \mathrm{~min}, 20^{\circ} \mathrm{C}\right.$ ). We separated the labeled proteins from excess label by using Ni-NTA resin, and measured EPR spectra before and after irradiation (Figure 3). Data recorded before irradiation indicate that the PPG is stable enough to survive the labeling and washing procedure. EPR spectra after irradiation show that both model proteins comprising $\mathbf{2}$ a or $\mathbf{3}$ a were successfully labeled and deprotection worked. Spectra of the wt proteins incubated with the PaNDA spin label exhibit no EPR signal; this indicates high chemoselectivity of this reaction (Figure 3, upper line).

By means of circular dichroism spectroscopy, we further proved that the labeled proteins kept their secondary structure throughout the process (Figure S20). By analyzing the double integral of the EPR spectra, we found that deprotection of the PaNDA spin label was maximal after 2 min of irradiation at $\lambda=$ $302 \mathrm{~nm}$ (Figure S21). To substantiate our data, full-length ESIMS spectra were recorded (Figures S18 and S19). Signals can be assigned to successfully labeled and deprotected protein, but no mass signals were found that corresponded to still protected protein-label complex (occurrence of signals with $\Delta=$ $-150 \mathrm{Da}$ for $\mathbf{2} \mathbf{a}$ or $\mathbf{2} \mathbf{b}$, or $\Delta=-152 \mathrm{Da}$ for $\mathbf{3} \mathbf{a}$ or $\mathbf{3} \mathbf{b}$ indicated partial degradation of the ncAA to lysine). Thus, the design of our spin label allows for fast and selective labeling, as well as convenient and quantitative deprotection.

We assessed the performance of our protection strategy in biological environments. We reasoned that reducing conditions could potentially intervene with the spontaneous oxidation step, converting the irradiation-derived hydroxylamine into a nitroxide. ${ }^{[22]}$ To this end, we chose E. coli lysate because it contained relevant cell components and provided reducing conditions. We first labeled TRX-R74 $\rightarrow \mathbf{2}$ a with the PaNDA spin label and deprotected the obtained TRX-R74 $\rightarrow \mathbf{2} \mathbf{b}$ as described above. Then we incubated the lysate with this protein to confirm nitroxide degradation. After $80 \mathrm{~min}$, the EPR signal was $<1 \mu \mathrm{M}$ (Figure 4). Then, we incubated labeled and still protected TRX-R74 $\rightarrow \mathbf{2}$ b with the same amount of fresh $E$. coli lysate for $80 \mathrm{~min}$. No EPR signal was detected in this period of time; this meant that the protecting group remained stable on the protein. After irradiation, the EPR signal increased; this resulted in approximately $50 \%$ spin concentration compared with deprotection in buffered solution.

This demonstrates that a spontaneous oxidation step to form the nitroxide is actually possible in a reducing environment, and that, in principle, deprotection can be performed in E. coli lysate to recover the EPR signal.

We envisage the application of the PaNDA spin label for incell EPR measurements. Points that need to be addressed before the system can be used in cells involve the delivery of the PaNDA spin label into cells and removal of unbound label. 
A)

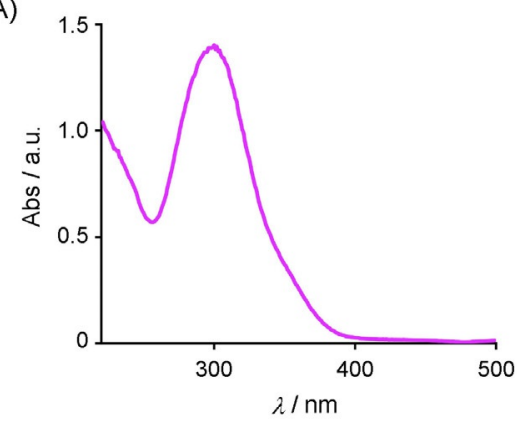

C)

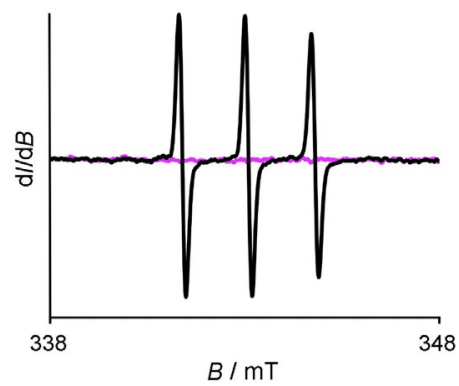

B)

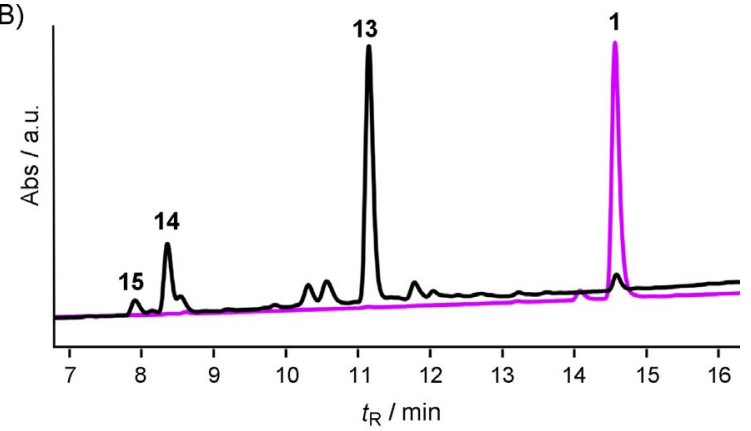

Figure 2. Deprotection study of the PaNDA spin label 1. A) UV absorption spectrum of $75 \mu \mathrm{M} 1$ in methanol. B) LC-MS traces showing the absorption at $\lambda=$ $254 \mathrm{~nm}$ of 1 before (purple) and after irradiation (black) for $10 \mathrm{~min}$ at $\lambda=302 \mathrm{~nm}$. After irradiation, label 1 is virtually completely consumed and nitroxide 13 is the main product. Small amounts of intermediate 14 and side product 15 are visible. C) EPR spectrum of $100 \mu \mathrm{M} 1$ in water before (purple) and after irradiation (black).

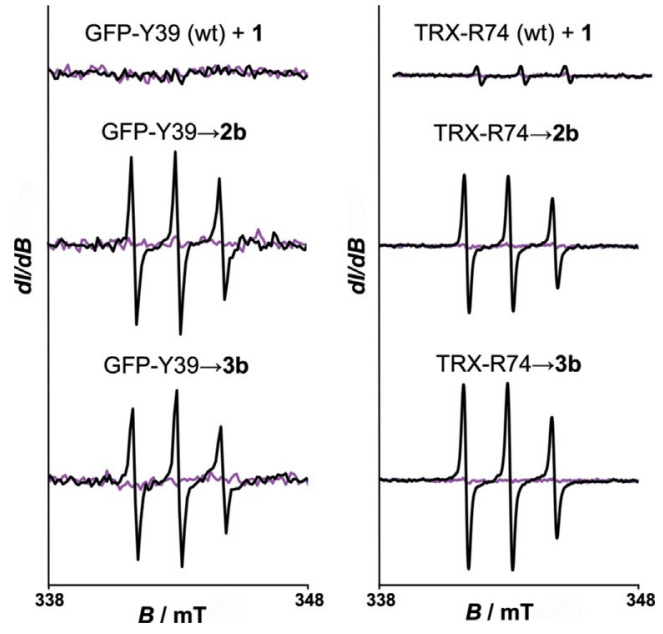

Figure 3. SDSL of proteins by $\mathrm{DA}_{\text {inv }}$ cycloaddition and subsequent deprotection of the PPG. EPR spectra of GFP and TRX bearing amino acids, as indicated (wild type (wt) shown in the first row) and reacted with the PaNDA spin label after purification. Spectra are shown before (purple) and after (black) irradiation. The signal intensities are drawn on the same scale for all spectra in one column. Approximately $1 \mu \mathrm{m}$ spin concentration for TRX-R74 (wt) +1 indicates minor remaining impurities of unreacted PaNDA after purification.

Moreover, labeling and deprotection efficiencies need to be confirmed in cells. However, the $\mathrm{DA}_{\text {inv }}$ reaction, in general, is known to be well suited to bioorthogonal intracellular reactions. $^{[37]}$ Moreover, o-nitrobenzyl and other PPGs were shown to be cleaved upon irradiation, even inside cells. ${ }^{[38]}$ To address

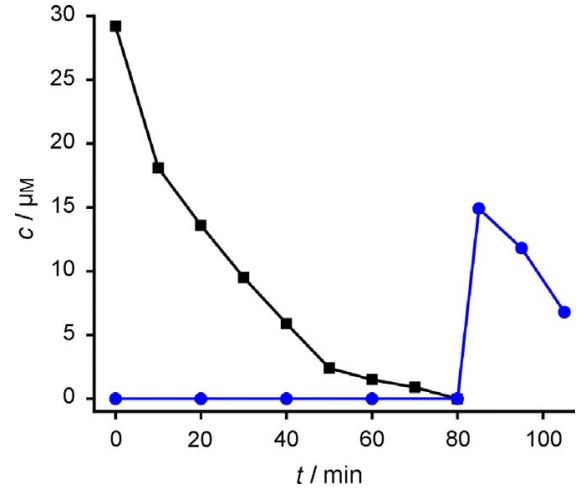

Figure 4. Recovery of nitroxide radicals is possible in E. coli lysate. E. coli cells were lysed and mixed with preliminarily irradiated TRX-R74 $\rightarrow \mathbf{2} \mathbf{b}(\mathbf{\square})$ and the spin concentration was quantified at different time points until the signal had vanished $(<1 \mu \mathrm{M})$ after $80 \mathrm{~min}$. In comparison, a nonirradiated sample of TRX-R74 $\rightarrow \mathbf{2}$ b ( $\bullet$ ) was incubated with lysate for $80 \mathrm{~min}$, showing no EPR signal. After irradiation for $2 \mathrm{~min}$ at $\lambda=302 \mathrm{~nm}$, a spin concentration of approximately $15 \mu \mathrm{M}$ was found (see Figure S22 for EPR spectra at each time point).

nitroxide lability after irradiation, samples for EPR distance measurements will be frozen directly after being irradiated; thus minimizing nitroxide degradation.

In conclusion, we have developed an innovative SDSL approach based on genetically encoded ncAAs amenable to $\mathrm{DA}_{\text {inv }}$ chemistry and on a newly designed spin label. The PaNDA spin label provides an appealing combination of a tetrazine moiety and a PPG. The use of $D A_{\text {inv }}$ chemistry for spin labeling illus- 
trates the assets and versatility of this reaction. For in-cell labeling or binding studies in cellular environments, the PPG potentially enables prolonged incubation times before data acquisition. Thus, our method opens up new vistas for the study of proteins by EPR spectroscopy.

\section{Acknowledgements}

This project has received funding from the European Research Council (ERC) under the European Union's Horizon 2020 research and innovation programme (grant agreement no. 772027-SPICEERC-2017-COG) and from the Deutsche Forschungsgemeinschaft (SFB 969, Projects B5 and C3). We thank Edward Lemke and Daniel Summerer for plasmid PEVOL_PyIRS_AF.

\section{Conflict of Interest}

The authors declare no conflict of interest.

Keywords: bioorthogonal chemistry • cycloaddition · EPR spectroscopy $\cdot$ noncanonical amino acids $\cdot$ site-directed spin labeling

[1] a) O. H. Griffith, P. C. Jost, in Spin Labeling, Vol. 1: Theory and Applications (Ed.: L. Berliner), Academic Press, New York, 1976, p. 453; b) C. Altenbach, T. Marti, H. G. Khorana, W. L. Hubbell, Science 1990, 248, 1088.

[2] a) O. H. Griffith, A. Waggoner, Acc. Chem. Res. 1969, 2, 17; b) W. L. Hubbell, C. J. López, C. Altenbach, Z. Yang, Curr. Opin. Struct. Biol. 2013, 23, 725.

[3] a) H. S. Mchaourab, M. A. Lietzow, K. Hideg, W. L. Hubbell, Biochemistry 1996, 35, 7692; b) P. Roser, M. J. Schmidt, M. Drescher, D. Summerer, Org. Biomol. Chem. 2016, 14, 5468.

[4] J. H. Freed in Spin Labeling: Theory and Applications, 1st ed. (Ed.: L. J. Berliner), Academic Press, New York, 1976, p. 53.

[5] G. Jeschke, Ann. Rev. Phys. Chem. 2012, 63, 419.

[6] a) E. Mileo, E. Etienne, M. Martinho, R. Lebrun, V. Roubaud, P. Tordo, B. Gontero, B. Guigliarelli, S. R. Marque, V. Belle, Bioconjugate Chem. 2013, 24, 1110; b) M. Lorenzi, C. Puppo, R. Lebrun, S. Lignon, V. Roubaud, M Martinho, E. Mileo, P. Tordo, S. R. Marque, B. Gontero, B. Guigliarelli, V. Belle, Angew. Chem. Int. Ed. 2011, 50, 9108; Angew. Chem. 2011, 123, 9274.

[7] T. Braun, M. Drescher, D. Summerer, Int. J. Mol. Sci. 2019, 20, 373.

[8] J. W. Chin, Nature 2017, 550, 53.

[9] K. Lang, J. W. Chin, Chem. Rev. 2014, 114, 4764.

[10] a) M. R. Fleissner, E. M. Brustad, T. Kálai, C. Altenbach, D. Cascio, F. B. Peters, K. Hideg, S. Peuker, P. G. Schultz, W. L. Hubbell, Proc. Natl. Acad. Sci. USA 2009, 106, 21637; b) E. H. Abdelkader, A. Feintuch, X. Yao, L. A. Adams, L. Aurelio, B. Graham, D. Goldfarb, G. Otting, Chem. Commun. 2015, 51, 15898; c) S. Kucher, S. Korneev, S. Tyagi, R. Apfelbaum, D. Grohmann, E. A. Lemke, J. P. Klare, H.-J. Steinhoff, D. Klose, J. Magn. Reson. 2017, 275, 38; d) T. Kálai, M. R. Fleissner, J. Jekő, W. L. Hubbell, K Hideg, Tetrahedron Lett. 2011, 52, 2747; e) M. J. Schmidt, J. Borbas, M. Drescher, D. Summerer, J. Am. Chem. Soc. 2014, 136, 1238; f) A. Kugele, T. S. Braun, P. Widder, L. Williams, M. J. Schmidt, D. Summerer, M. Drescher, Chem. Commun. 2019, 55, 1923; g) P. Widder, F. Berner, D. Summerer, M. Drescher, ACS Chem. Biol. 2019, 14, 839.

[11] a) M. Qi, A. Groß, G. Jeschke, A. Godt, M. Drescher, J. Am. Chem. Soc. 2014, 136, 15366; b) A. Martorana, G. Bellapadrona, A. Feintuch, E. Di Gregorio, S. Aime, D. Goldfarb, J. Am. Chem. Soc. 2014, 136, 13458; c) E. H. Abdelkader, M. D. Lee, A. Feintuch, M. R. Cohen, J. D. Swarbrick, G. Otting, B. Graham, D. Goldfarb, J. Phys. Chem. Lett. 2015, 6, 5016; d) B. Joseph, V. M. Tormyshev, O. Y. Rogozhnikova, D. Akhmetzyanov, E. G. Bagryanskaya, T. F. Prisner, Angew. Chem. Int. Ed. 2016, 55, 11538;
Angew. Chem. 2016, 128, 11710; e) J. J. Jassoy, A. Berndhäuser, F. Duthie, S. P. Kühn, G. Hagelueken, O. Schiemann, Angew. Chem. 2017, 129, 183.

[12] M. Azarkh, O. Okle, P. Eyring, D. R. Dietrich, M. Drescher, J. Magn. Reson. 2011, 212, 450.

[13] G. Karthikeyan, A. Bonucci, G. Casano, G. Gerbaud, S. Abel, V. Thomé, L. Kodjabachian, A. Magalon, B. Guigliarelli, V. Belle, O. Ouari, E. Mileo, Angew. Chem. Int. Ed. 2018, 57, 1366; Angew. Chem. 2018, 130, 1380

[14] a) R. Carboni, R. Lindsey, Jr., J. Am. Chem. Soc. 1959, 81, 4342; b) M. F. Debets, S. S. van Berkel, J. Dommerholt, A. J. Dirks, F. P. J. T. Rutjes, F. L. van Delft, Acc. Chem. Res. 2011, 44, 805; c) A.-C. Knall, C. Slugovc, Chem. Soc. Rev. 2013, 42, 5131; d) H. Wu, N. K. Devaraj, Top. Curr. Chem. 2016, 374, 3; e) E. Kozma, O. Demeter, P. Kele, ChemBioChem 2017, 18, 486; f) B. Oliveira, Z. Guo, G. Bernardes, Chem. Soc. Rev. 2017, 46, 4895; g) S. Mayer, K. Lang, Synthesis 2017, 49, 830.

[15] a) T. Plass, S. Milles, C. Koehler, J. Szymański, R. Mueller, M. Wießler, C. Schultz, E. A. Lemke, Angew. Chem. Int. Ed. 2012, 51, 4166; Angew. Chem. 2012, 124, 4242; b) I. Nikić, T. Plass, O. Schraidt, J. Szymański, J. A. G. Briggs, C. Schultz, E. A. Lemke, Angew. Chem. Int. Ed. 2014, 53, 2245; Angew. Chem. 2014, 126, 2278.

[16] a) M. L. Blackman, M. Royzen, J. M. Fox, J. Am. Chem. Soc. 2008, 130, 13518 ; b) R. Rossin, P. Renart Verkerk, S. M. van den Bosch, R. C. M. Vulders, I. Verel, J. Lub, M. S. Robillard, Angew. Chem. Int. Ed. 2010, 49, 3375; Angew. Chem. 2010, 122, 3447; c) K. Lang, L. Davis, S. Wallace, M. Mahesh, D. J. Cox, M. L. Blackman, J. M. Fox, J. W. Chin, J. Am. Chem. Soc. 2012, 134, 10317; d) J. Schoch, M. Staudt, A. Samanta, M. Wiessler, A. Jäschke, Bioconjugate Chem. 2012, 23, 1382.

[17] F. Doll, A. Buntz, A.-K. Späte, V. F. Schart, A. Timper, W. Schrimpf, C. R. Hauck, A. Zumbusch, V. Wittmann, Angew. Chem. Int. Ed. 2016, 55, 2262; Angew. Chem. 2016, 128, 2303.

[18] C. Domnick, G. Hagelueken, F. Eggert, O. Schiemann, S. Kath-Schorr, Org. Biomol. Chem. 2019, 17, 1805.

[19] B. A. Chalmers, J. C. Morris, K. E. Fairfull-Smith, R. S. Grainger, S. E. Bottle, Chem. Commun. 2013, 49, 10382.

[20] J. F. Keana, G. S. Heo, G. T. Gaughan, J. Org. Chem. 1985, 50, 2346.

[21] E. John, J. Chem. Soc. Perkin Trans. 1 1991, 2243.

[22] I. Seven, T. Weinrich, M. Gränz, C. Grünewald, S. Brüß, I. Krstić, T. F. Prisner, A. Heckel, M. W. Göbel, Eur. J. Org. Chem. 2014, 4037.

[23] A. Dumas, L. Lercher, C. D. Spicer, B. G. Davis, Chem. Sci. 2015, 6, 50.

[24] a) P. Wang, Asian J. Org. Chem. 2013, 2, 452; b) J. Barltrop, P. Plant, P. Schofield, Chem. Commun. 1966, 822; c) A. Patchornik, B. Amit, R. Woodward, J. Am. Chem. Soc. 1970, 92, 6333; d) C. G. Bochet, J. Chem. Soc. Perkin Trans. 1 2002, 125; e) J. W. Walker, G. P. Reid, J. A. McCray, D. R. Trentham, J. Am. Chem. Soc. 1988, 110, 7170; f) Y. V. I'ichev, M. A. Schwörer, J. Wirz, J. Am. Chem. Soc. 2004, 126, 4581.

[25] a) T. Weinrich, M. Gränz, C. Grünewald, T. F. Prisner, M. W. Göbel, Eur. J. Org. Chem. 2017, 491; b) T. Weinrich, E. A. Jaumann, U. Scheffer, T. F. Prisner, M. W. Göbel, Chem. Eur. J. 2018, 24, 6202.

[26] A. Niederwieser, A. K. Späte, L. D. Nguyen, C. Jüngst, W. Reutter, V. Wittmann, Angew. Chem. Int. Ed. 2013, 52, 4265; Angew. Chem. 2013, 125, 4359.

[27] S. K. Katti, D. M. LeMaster, H. Eklund, J. Mol. Biol. 1990, 212, 167.

[28] V. D. Sen', I. V. Tikhonov, L. I. Borodin, E. M. Pliss, V. A. Golubev, M. A. Syroeshkin, A. I. Rusakov, J. Phys. Org. Chem. 2015, 28, 17.

[29] L. I. Willems, N. Li, B. I. Florea, M. Ruben, G. A. van der Marel, H. S. Overkleeft, Angew. Chem. Int. Ed. 2012, 51, 4431; Angew. Chem. 2012, 124, 4507.

[30] a) M. J. Schmidt, A. Fedoseev, D. Bücker, J. Borbas, C. Peter, M. Drescher, D. Summerer, ACS Chem. Biol. 2015, 10, 2764; b) A. Kugele, T. Braun, P. Widder, L. Williams, M. J. Schmidt, D. Summerer, M. Drescher, Chem. Commun. 2019, 55, 1923.

[31] T. Plass, S. Milles, C. Koehler, C. Schultz, E. A. Lemke, Angew. Chem. Int. Ed. 2011, 50, 3878; Angew. Chem. 2011, 123, 3964.

[32] J. L. Seitchik, J. C. Peeler, M. T. Taylor, M. L. Blackman, T. W. Rhoads, R. B. Cooley, C. Refakis, J. M. Fox, R. A. Mehl, J. Am. Chem. Soc. 2012, 134, 2898.

[33] K. Lang, L. Davis, J. Torres-Kolbus, C. Chou, A. Deiters, J. W. Chin, Nat Chem. 2012, 4, 298.

[34] C. P. Ramil, M. Dong, P. An, T. M. Lewandowski, Z. Yu, L. J. Miller, Q. Lin, J. Am. Chem. Soc. 2017, 139, 13376.

[35] T. Yanagisawa, R. Ishii, R. Fukunaga, T. Kobayashi, K. Sakamoto, S. Yokoyama, Chem. Biol. 2008, 15, 1187. 
[36] M. J. Schmidt, D. Summerer, ChemBioChem 2012, 13, 1553.

[37] H. Wu, N. K. Devaraj in Cycloadditions in Bioorthogonal Chemistry (Eds.: M. Vrabel, T. Carell), Springer, 2016, p. 109.

[38] a) A. Yamada, M. Abe, Y. Nishimura, S. Ishizaka, M. Namba, T. Nakashima, K. Shimoji, N. Hattori, Beilstein J. Org. Chem. 2019, 15, 863; b) P. Klán, T. Solomek, C. G. Bochet, A. L. Blanc, R. Givens, M. Rubina, V. Popik, A. Kostikov, J. Wirz, Chem. Rev. 2013, 113, 119; c) S. Chalmers, S. T. Caldwell, C. Quin, T. A. Prime, A. M. James, A. G. Cairns, M. P. Murphy, J. G. McCarron, R. C. Hartley, J. Am. Chem. Soc. 2012, 134, 758; d) W. F. Veldhuyzen, Q. Nguyen, G. McMaster, D. S. Lawrence, J. Am. Chem. Soc. 2003, 125,
13358; e) K. Furukawa, H. Abe, S. Tsuneda, Y. Ito, Org. Biomol. Chem. 2010, 8, 2309; f) H.-L. D. Lee, S. J. Lord, S. Iwanaga, K. Zhan, H. Xie, J. C. Williams, H. Wang, G. R. Bowman, E. D. Goley, L. Shapiro, J. Am. Chem Soc. 2010, 132, 15099

Manuscript received: May 13, 2019

Accepted manuscript online: May 15, 2019

Version of record online: August 14, 2019 